Institut für Makroökonomie und Konjunkturforschung Macroeconomic Policy Institute
Working Paper

\title{
Inequality and Growth in Neo-Kaleckian and Cambridge Growth Theory ${ }^{* *}$
}

\author{
Revised April 19, 2016
}

\section{Abstract}

This paper examines the relationship between inequality and growth in the neo-Kaleckian and Cambridge growth models. The paper explores the channels whereby functional and personal income distribution impact growth. The growth - inequality relationship can be negative or positive, depending on the economy's characteristics. Contrary to widespread claims, inequality per se does not impact growth through macroeconomic channels. Instead, both growth and inequality are impacted by changes in the underlying forms and pattern of income payments. However, inequality is critical at the microeconomic level as it explains differences in household propensities to consume which are at the foundation of neo-Kaleckian and Cambridge growth theory.

Keywords: Income inequality, growth, neo-Kaleckian theory, Cambridge growth theory

JEL refs.: E0, E12, E25

\footnotetext{
* Thomas I. Palley, Senior Economic Policy Adviser, AFL-CIO, mail@thomaspalley.com

** Bhaduri and Marglin (1990) use the terminology of stagnationist, exhilarationist, and conflictive. Dutt (1984) deserves special recognition. In his model, if the Keynesian expenditure multiplier stability condition holds, the economy can only be wage-led or conflictive. Bhaduri and Marglin reformulated investment spending to depend on the profit share rather than the profit rate, which then enables the economy to be potentially profit-led. However, the microeconomic rationale for this formulation is open to question. Blecker (2002, p.135-138) has a comprehensive discussion of this issue.
} 


\title{
Inequality and Growth in Neo-Kaleckian and Cambridge Growth Theory ${ }^{1}$
}

\begin{abstract}
This paper examines the relationship between inequality and growth in the neo-Kaleckian and Cambridge growth models. The paper explores the channels whereby functional and personal income distribution impact growth. The growth - inequality relationship can be negative or positive, depending on the economy's characteristics. Contrary to widespread claims, inequality per se does not impact growth through macroeconomic channels. Instead, both growth and inequality are impacted by changes in the underlying forms and pattern of income payments. However, inequality is critical at the microeconomic level as it explains differences in household propensities to consume which are at the foundation of neo-Kaleckian and Cambridge growth theory.
\end{abstract}

Key words: Income inequality, growth, neo-Kaleckian theory, Cambridge growth theory JEL ref.: E0, E12, E25

Thomas I. Palley

Independent analyst

mail@thomaspalley.com

Revised April 19, 2016

\section{Introduction: the new research agenda of inequality}

Bhaduri and Marglin’s (B\&M, 1990) paper, “Unemployment and the real wage: the economic basis for contesting political ideologies”, has become a Post Keynesian classic. Building on earlier work by Rowthorn (1982), Taylor (1983), and Dutt (1984), B\&M introduced the distinction between wage-led, profit-led, and conflictive growth regimes. ${ }^{2}$

B\&M’s analytical focus was the impact of the real wage and the wage share on unemployment and growth, which has long been a central concern of macroeconomics. The traditional macroeconomic frame has classical economists claiming that a higher real

\footnotetext{
1 The author thanks an anonymous referee for comments and retains all responsibility for errors.

2 Bhaduri and Marglin (1990) use the terminology of stagnationist, exhilarationist, and conflictive. Dutt (1984) deserves special recognition. In his model, if the Keynesian expenditure multiplier stability condition holds, the economy can only be wage-led or conflictive. Bhaduri and Marglin reformulated investment spending to depend on the profit share rather than the profit rate, which then enables the economy to be potentially profit-led. However, the microeconomic rationale for this formulation is open to question. Blecker (2002, p.135-138) has a comprehensive discussion of this issue.
} 
wage lowers employment by reducing firms' demand for labor as determined by the marginal product of labor schedule, while Keynesian economists claim it can increase employment by increasing aggregate demand. B\&M sought to resituate this historic debate in a Keynes-Kalecki aggregate demand framework. According to that framework, the Keynesian position remains that a higher real wage and wage share can increase employment by increasing aggregate demand. However, the classical position is reinterpreted as an argument that a higher real wage and wage share can reduce employment by lowering the profit share and investment spending.

The focus on real wages and the wage share reflected the political economy concerns of the 1970s and 1980s. This was a period of significant labor - capital conflict, marked by the rise of neoliberalism which aimed to tame labor and shift the distribution of income toward capital. Since then the focus of concern has shifted to income inequality, which has increased dramatically during the neoliberal era (i.e. late 1970s to the present) as documented in Piketty's (2014) blockbuster best-seller, Capital in the Twenty-First Century. This increase in income inequality has triggered a second generation research agenda (see for instance Carvalho and Rezai, 2015), that aims to explain both the cause of increased income inequality and the impact of inequality of growth.

This paper explores the relationship between income inequality and growth, using a modified version of the B\&M model developed by Palley (2005, 2014a, 2015a, 2015b). The B\&M model only addresses issues concerning the functional distribution of income (i.e. the wage - profit share), rendering it unable to address inequality which depends on the personal distribution of income. The modified model shows how the functional distribution of income is transformed into personal income distribution. 
The paper explores the different channels of impact of income distribution on growth and inequality in the neo-Kaleckian and Cambridge growth models, which are the two core Post Keynesian growth models. For each model, the paper analyzes the impact of income distribution in the short run (when wealth ownership is fixed) and the long run (when wealth ownership is endogenously determined).

The relationship between growth and inequality can be negative or positive, depending on the economy's characteristics. Contrary to widespread claims, inequality per se does not impact growth. Instead, both growth and inequality are impacted by changes in the underlying form and pattern of income payments.

\section{The structure of income distribution and inequality}

The starting point of the analysis is the structure of income distribution. Figure 1 describes the structure of income distribution in the B\&M model. Income is divided into profits and wages, with the profit and wage share being determined by firms' mark-up in accordance with Kaleckian mark-up pricing theory. All profit income accrues to capitalists, and all wage income accrues to workers. This pattern reflects two assumptions. First, capitalists

are assumed to receive no labor income (wages). Second, workers are assumed to consume all their income and have zero saving. Since workers save nothing, they have no ownership share and receive no share of profits. The corollary of that is capitalists receive all profit income. 
Figure 1. Income and wealth distribution in the Bhaduri - Marglin model.

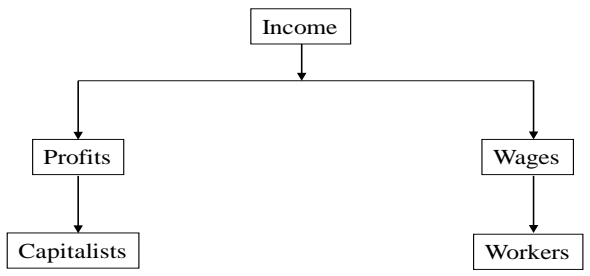

Figure 2 describes an alternative structure of income and wealth distribution as used by Palley (2005, 2014a, 2014b, 2015a, 2015b). There are two critical changes from Figure 1. First, capitalists are identified as capitalist-managers and they receive some wage income in their role as managers. Second, workers have a positive propensity to save so that they own part of the capital stock (wealth) and therefore receive a share of profits.

Figure 2. Income and wealth distribution in the Palley model.

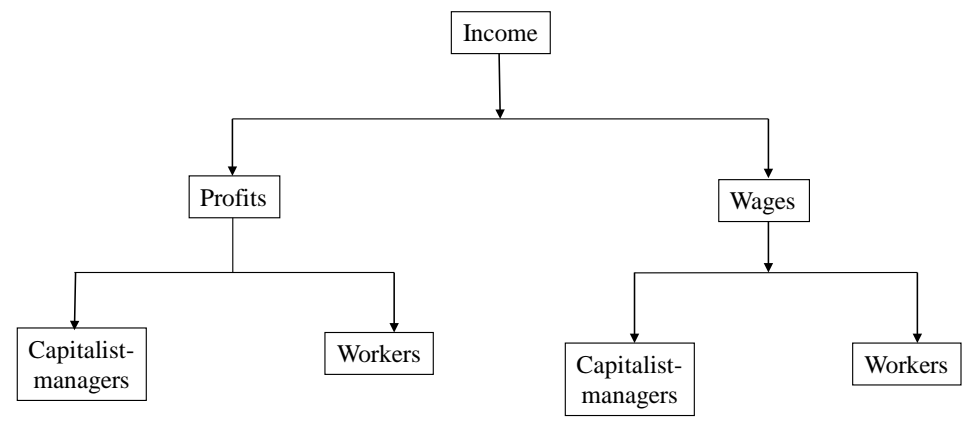

The equations of income, income distribution, and wealth ownership are as follows:

(1) $\mathrm{Y}=\mathrm{W}+\Pi$ 
(2) $\mathrm{W}=[1-\mathrm{z}] \mathrm{Y}$

(3) $\Pi=z Y$

(4) $\varphi_{K}+\varphi_{L}=1$

$0 \leq \varphi_{\mathrm{K}} \leq 1,0 \leq \varphi_{\mathrm{L}} \leq 1$

(5) $\sigma_{\mathrm{K}}+\sigma_{\mathrm{L}}=1$

$\sigma_{\mathrm{K}}>\sigma_{\mathrm{L}}, \varphi_{\mathrm{K}}<\varphi_{\mathrm{L}}, \sigma_{\mathrm{K}}>\varphi_{\mathrm{K}}, \sigma_{\mathrm{L}}<\varphi_{\mathrm{L}}$

$\mathrm{Y}=$ income, $\mathrm{W}=$ wage bill, $\Pi=$ profits, $\mathrm{z}=$ profit share of income, $\varphi_{\mathrm{K}}=$

capitalist-managers' share of the wage bill, $\varphi_{\mathrm{L}}=$ workers' share of the wage bill, $\sigma_{\mathrm{K}}=$ capitalist-managers' ownership share, and $\sigma_{\mathrm{L}}=$ workers' ownership share. The inequality restrictions on wage and ownership shares ensure that capitalist-managers own the bulk of the capital stock and get the bulk of their income from profits, while workers get the bulk of their income from wages.

The worker household and capitalist-manager household share of income distribution are given respectively by

(6) $\mathrm{y}_{\mathrm{W}}=\left[\varphi_{\mathrm{L}} \mathrm{W}+\sigma_{\mathrm{L}} \Pi\right] / \mathrm{Y}$

(7) $\mathrm{y}_{\mathrm{K}}=\left[\varphi_{\mathrm{K}} \mathrm{W}+\sigma_{\mathrm{K}} \Pi\right] / \mathrm{Y}$

$\mathrm{y}_{\mathrm{W}}=$ worker household income share, $\mathrm{y}_{\mathrm{K}}=$ capitalist-manager household income share.

Equations (6) and (7) can be viewed as describing the personal distribution of income in an economy with two types of household.

By appropriate substitution, using equations (1) - (7), it can then be shown

(8) $y_{W}+y_{K}=1$

(9) $\mathrm{y}_{\mathrm{W}}=\varphi_{\mathrm{L}}[1-\mathrm{z}]+\sigma_{\mathrm{L}} \mathrm{z}$

(10) $\mathrm{y}_{\mathrm{K}}=\varphi_{\mathrm{K}}[1-\mathrm{z}]+\sigma_{\mathrm{K}} \mathrm{Z}$

Equations (9) and (10) determine the personal distribution of income in Figure 2. They contrast with the personal distribution of income in Figure 1 which is given by 
(9.a) $\mathrm{y}_{\mathrm{w}}=[1-\mathrm{z}]$

(10.a) $\mathrm{y}_{\mathrm{K}}=\mathrm{z}$

Worker household income share is equal to the wage share, while capitalist-manager household income share is equal to the profit share. In the B\&M model the personal distribution of income is therefore identical to the functional distribution of income.

The next step is to define income inequality which, for a two type household economy, is defined as the ratio of household incomes and is given by

(11) $\psi=\mathrm{y}_{\mathrm{K}} / \mathrm{y}_{\mathrm{W}}$

$\psi=$ index of income inequality. For a given level of total income, increased capitalist household income raises income inequality, while increased worker household income lowers income inequality. For the B\&M model, income inequality is given by (11.a) $\psi=\mathrm{z} /[1-\mathrm{z}]$

The functional distribution of income uniquely determines the level of income inequality. For the Palley model, income inequality is given by (11.b) $\psi=\left\{\varphi_{K}[1-z]+\sigma_{K} Z\right\} /\left\{\varphi_{L}[1-z]+\sigma_{L} Z\right\}$

Now, income inequality depends on the functional distribution of income, the division of the wage bill, and the ownership distribution of the capital stock.

Table 1 shows the signs of the comparative static responses of the index of income inequality with respect to changes in the underlying parameters determining income inequality. These signings use the restrictions imposed earlier on ownership and wage bill shares. A higher profit share (lower wage share) increases inequality by increasing capitalist-managers' share of income. A higher worker ownership share of the capital stock (lower capitalist-manager ownership share) lowers income inequality, as does a higher 
worker wage bill share (lower capitalist-manager wage bill share).

Table 1. Comparative static responses of income inequality.

\begin{tabular}{|l|c|c|c|c|c|}
\hline & $d \mathrm{z}>0$ & $d \varphi_{\mathrm{L}}>0$ & $d \varphi_{\mathrm{K}}>0$ & $d \sigma_{\mathrm{L}}>0$ & $d \sigma_{\mathrm{K}}>0$ \\
\hline$d \psi$ & + & - & + & - & + \\
\hline
\end{tabular}

\section{Inequality and growth in the neo-Kaleckian model: the short run}

The next step is specification of the neo-Kaleckian growth model, which is given by

(12) $\mathrm{I} / \mathrm{K}=I=\alpha_{0}+\alpha_{1} \mathrm{u}+\alpha_{2} \mathrm{Z}+\alpha_{3} \pi$

$$
\alpha_{0}>0, \alpha_{1}>0, \alpha_{2}>0, \alpha_{3}>0
$$

(13) $\pi=\mathrm{zu}$

(14) $S=S_{\mathrm{K}}+S_{\mathrm{L}}$

(15) $S_{\mathrm{K}}=\beta_{\mathrm{K}}\left\{\left[1-\varphi_{\mathrm{L}}\right][1-\mathrm{z}] \mathrm{u}+\left[1-\sigma_{\mathrm{L}}\right] \mathrm{zu}\right\}$

$$
0<\beta_{\mathrm{L}}<\beta_{\mathrm{K}} \leq 1
$$

(16) $S_{\mathrm{L}}=\beta_{\mathrm{L}}\left\{\varphi_{\mathrm{L}}[1-\mathrm{z}] \mathrm{u}+\sigma_{\mathrm{L}} \mathrm{zu}\right\}$

$$
0<\beta_{\mathrm{L}} \leq 1
$$

(17) $I=S$

(18) $g=\mathrm{I} / \mathrm{K}$

$\mathrm{I}=$ investment, $\mathrm{K}=$ capital stock, $\mathrm{u}=$ capacity utilization rate $(\mathrm{Y} / \mathrm{K}), \pi=$ profit rate $(\Pi / \mathrm{K})$, $S=$ aggregate saving per unit of capital, $S_{\mathrm{K}}=$ capitalist-managers' saving per unit of capital, $S_{\mathrm{L}}=$ workers' saving per unit of capital, $\beta_{\mathrm{K}}=$ capitalist-managers' propensity to save, and $\beta_{\mathrm{L}}$ = workers' propensity to save.

Equation (12) determines the rate of capital accumulation which is a positive function of capacity utilization, the profit share and the profit rate. The inclusion of both a profit share and a profit rate effect is necessary to ensure that the economy can exhibit 
profit-led behavior while simultaneously satisfying the Keynesian expenditure multiplier stability condition. Blecker (2002, p.137) terms this the "strong profit share effect".

Equation (13) determines the profit rate which equals the product of the profit share and the rate of capacity utilization. The profit share is assumed to be determined in accordance with Kaleckian distribution theory and is a positive function of firms' power to set the price mark-up. That power can reflect both goods market monopoly power and labor market bargaining power. ${ }^{3}$ Equation (14) defines the aggregate saving rate which is determined by capitalist-manager and worker saving. Equation (15) determines capitalist saving out of their share of wage and profit income, while equation (16) determines workers' saving out of their share of wage and profit income. Equation (17) is the dynamic IS condition that ensures goods market clearing and investment - saving balance. Equation (18) determines the growth rate which is equal to the rate of capital accumulation. For simplicity, depreciation is assumed to be zero so that the distinction between gross and net capital formation can be ignored.

Combing equations (14), (15), and (16) yields:

(19) $S=\beta_{\mathrm{L}}\left\{\varphi_{\mathrm{L}}[1-\mathrm{z}] \mathrm{u}+\sigma_{\mathrm{L}} \mathrm{zu}\right\}+\beta_{\mathrm{K}}\left\{\left[1-\varphi_{\mathrm{L}}\right][1-\mathrm{z}] \mathrm{u}+\left[1-\sigma_{\mathrm{L}}\right] \mathrm{zu}\right\}$

Differentiating (19) with respect to $\mathrm{z}, \varphi_{\mathrm{L}}$, and $\sigma_{\mathrm{L}}$ yields

$d S / d z=\left[\beta_{L}-\beta_{K}\right]\left[\sigma_{L}-\varphi_{L}\right] u>0$

$d S / d \varphi_{\mathrm{L}}=\left[\beta_{\mathrm{L}}-\beta_{\mathrm{K}}\right][1-\mathrm{z}] \mathrm{u}<0$

$d S / d \sigma_{\mathrm{L}}=\left[\beta_{\mathrm{L}}-\beta_{\mathrm{K}}\right] \mathrm{zu}<0$

An increase in the profit share increases aggregate saving. As workers receive a smaller share of profits than they do of wages $\left(\sigma_{\mathrm{L}}<\varphi_{\mathrm{L}}\right)$, a higher profit share transfers income from

\footnotetext{
${ }^{3}$ In the Kaleckian model prices are a mark-up over normal labor costs per unit of output and the profit share is given by $\mathrm{z}=\mathrm{m} /[1+\mathrm{m}]$ where $\mathrm{m}=$ the mark-up. The price of output is given by $\mathrm{p}=[1+\mathrm{m}] \mathrm{w} / \mathrm{a}$ where $\mathrm{p}=$ price, $\mathrm{w}=$ nominal wage, and $\mathrm{a}=$ normal labor productivity
} 
workers to capitalist-managers, and the latter have a higher propensity to save. An increase in workers' share of the wage bill transfers wage income from high-saving capitalist-managers to lower saving workers, causing aggregate saving to fall. An increase in workers’ ownership share transfers profit income from high-saving capitalist-managers to lower saving workers, causing aggregate saving to fall.

The B\&M neo-Kaleckian growth model has three regimes: wage-led, conflictive, and profit-led. These regimes refer to the impact of an exogenous change in the profit share. In a wage-led regime, a higher profit share lowers capacity utilization and growth. In a conflictive regime, a higher profit share lowers capacity utilization but increases growth. In a profit-led regime, a higher profit share raises capacity utilization and growth. The different regimes can be characterized by reference to the slope of the IS schedule in [u, z] space. A wage-led regime is characterized by a relatively flat negatively sloped IS; a conflictive regime is characterized by a relatively steep negatively sloped IS; and a profit-led regime is characterized by a positively sloped IS.

The full expression for the IS schedule is derived from equations (12), (17) and (19) and is given by

(20) $\alpha_{0}+\alpha_{1} u+\alpha_{2} z+\alpha_{3} z u=\beta_{L}\left\{\varphi_{L}[1-z] u+\sigma_{L} z u\right\}+\beta_{K}\left\{\left[1-\varphi_{L}\right][1-z] u+\left[1-\sigma_{L}\right] z u\right\}$

Its slope is:

$$
\begin{array}{r}
d z / d u=\left[S_{u}-I_{u}\right] /\left[I_{z}-S_{z}\right]=\left\{\beta_{L}\left\{\varphi_{L}[1-z]+\sigma_{L} z\right\}+\beta_{K}\left\{\left[1-\varphi_{L}\right][1-z]+\left[1-\sigma_{L}\right] z\right\}-\alpha_{1}-\alpha_{3} Z\right\} / \\
\left\{\alpha_{2}+\left\{\alpha_{3}-\beta_{L}\left\{\sigma_{L}-\varphi_{L}\right\}-\beta_{K}\left\{\left[1-\sigma_{L}\right]-\left[1-\varphi_{L}\right]\right\}\right\} u\right\} \text { The }
\end{array}
$$

slope depends on all three distributional parameters $\left(\mathrm{z}, \varphi_{\mathrm{L}}\right.$, and $\left.\sigma_{\mathrm{L}}\right)$. If the Keynesian multiplier stability condition $\left(S_{\mathrm{u}}-I_{\mathrm{u}}>0\right)$ holds, the numerator is positive and the sign of the slope of the IS depends exclusively on the sign of the denominator. The economy is 
wage-led or conflictive if the denominator is negative, and profit-led if it is positive. Changes in the profit share (z) have no effect on the denominator so that changes in the functional distribution of income have no impact on whether an economy is wage-led or profit-led. Increases in workers' ownership share $\left(\sigma_{\mathrm{L}}\right)$ increase the denominator, making it more likely that it is positive and the economy is profit-led. Increases in workers' wage share $\left(\varphi_{\mathrm{L}}\right)$ reduce the denominator, making it more likely that it is negative and the economy is wage-led.

We are now in a position to examine the relationship between growth and inequality. The first step is to examine the relationship in the short run, which is defined as a situation in which ownership shares of the capital stock are exogenously given. Later, we will examine the long run relationship which allows ownership shares to vary endogenously in response to differences in household relative saving rates.

Figure 3 describes a wage-led economy. The northeast quadrant shows a relatively flat negatively sloped IS schedule (equation (20)) and profit share function (equation (13)) which is denoted PP. For simplicity, the profit share is assumed to be exogenous and independent of the rate of capacity utilization. The southeast quadrant shows the accumulation function (equation (18)), which is denoted GG and determines the rate of growth as a positive function of the rate of capacity utilization. The northwest quadrant shows the level of inequality as a function of the profit share (equation (11.b)). The function is denoted $\Psi \Psi$ and the relationship is positive, with a higher profit share generating increased inequality. 
Figure 3. The neo-Kaleckian model with an index of inequality for a wage-led economy.

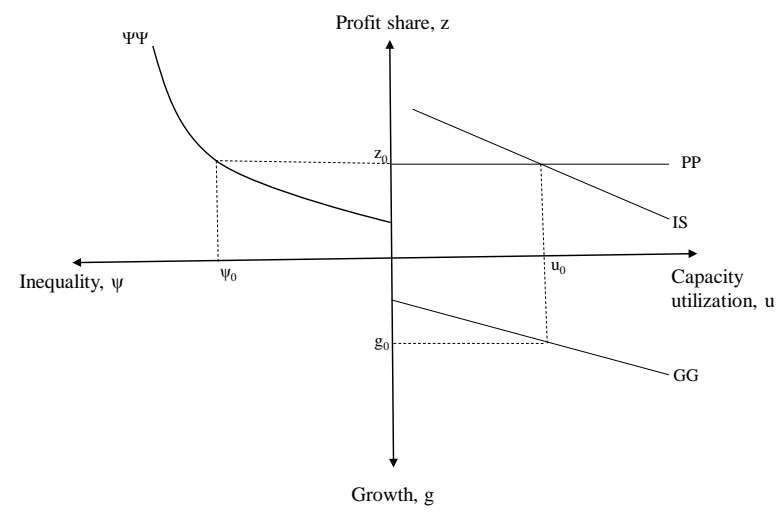

The model and Figure 3 can now be used to understand the relationship between inequality and growth. The first experiment is an increase in aggregate demand growth due to a lower capitalist-manager propensity to save $\left(\beta_{\mathrm{K}}\right)$ or a lower worker propensity to save $\left(\beta_{\mathrm{W}}\right)$. As illustrated in Figure 4, each of these changes shifts the IS right, increasing capacity utilization and growth while leaving inequality unchanged. There is therefore no trade-off between equality and growth. The growth - inequality locus is therefore a vertical line. 
Figure 4. The effect of stronger demand growth on growth and inequality in a wage-led economy.

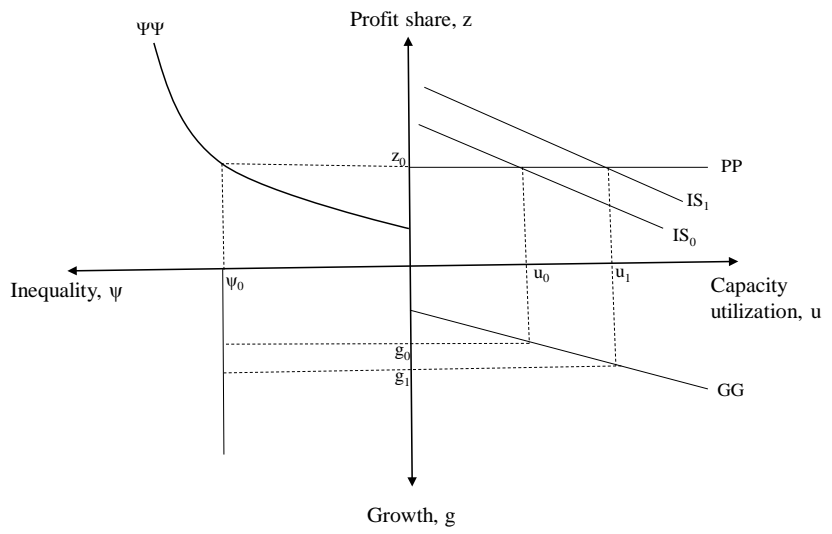

The second experiment is an increase in aggregate demand growth due to improved animal spirits $\left(\alpha_{0}\right)$. Once again this shifts the IS right but it also shifts the growth function in the southeast quadrant. Consequently, growth increases even more due to the combination of increased animal spirits, increased capacity utilization, and an increased profit rate. However, inequality is again unaffected.

The third experiment is an increase in the profit share due to increase in the price mark-up. Such an increase may be due to either increased firm monopoly power or decreased worker bargaining power. As illustrated in Figure 5, this shifts up the PP function, and also shifts ( $\alpha_{2} \mathrm{Z}$ effect) and rotates ( $\alpha_{3} \mathrm{zu}$ effect) the growth function in the southeast quadrant. The net result is lower growth because the economy is wage-led and increased inequality, so that the growth inequality relationship traced out in the southwest quadrant is negatively sloped. Again there is no trade-off between equality and growth because lower inequality (greater equality) from a lower profit share actually increases growth. 
Figure 5. The effect of an increased profit share on growth and inequality in a wage-led economy.

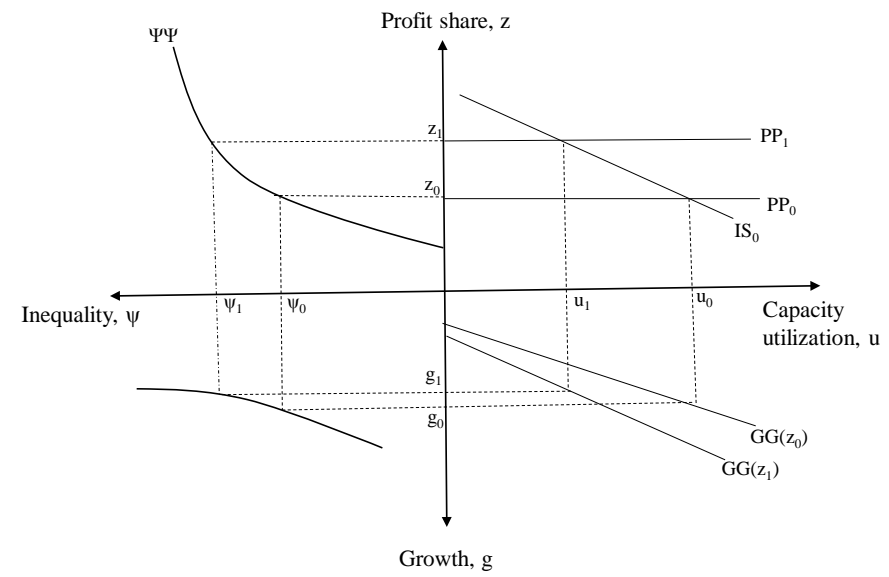

A fourth set of experiments concerns the effect on growth and inequality of an increases in capitalist-managers' share of the wage bill $\left(\varphi_{K}\right)$ and ownership share $\left(\sigma_{K}\right)$, which is equivalent to a reduction in workers' share of the wage bill $\left(\varphi_{\mathrm{L}}\right)$ and ownership $\operatorname{share}\left(\sigma_{L}\right)$. As illustrated in Figure 6, both of these changes $\left(\Delta \varphi_{K}, \Delta \sigma_{K}\right)$ reduce aggregate demand and shift the IS left in the northeast quadrant. They both also increase inequality and shift the inequality function left in the northwest quadrant. In both cases, the net result is inequality increases and growth decreases, generating a negatively sloped locus in the southwest quadrant. That means there is again no trade-off between equality and growth, and higher growth is associated with greater equality. 
Figure 6. The effect of an increase in capitalist-managers' wage share or ownership share on growth and inequality in a wage-led economy.

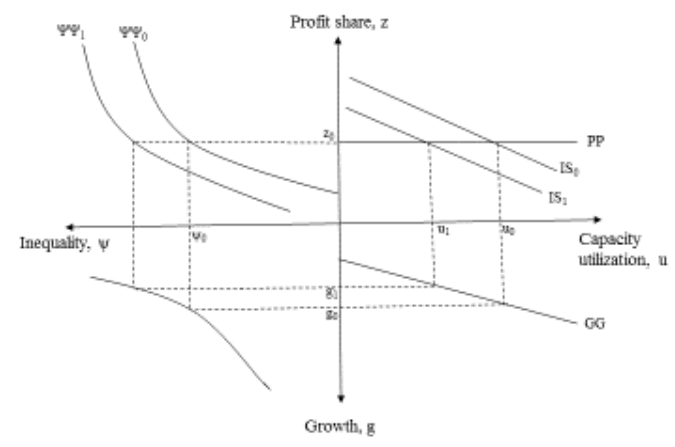

Similar experiments can be conducted for conflictive and profit-led economies. In a conflictive economy the IS schedule remains negatively sloped but the absolute value of the slope is greater. In a profit-led economy the IS schedule is positively sloped. Tables 3, 4 and 5 summarize the comparative static effects of these experiments in wage-led, conflictive, and profit-led economies. The exogenous variables can be divided into macroeconomic parameters $\left(\alpha_{0}, \beta_{\mathrm{K}}, \beta_{\mathrm{L}}\right)$ and distributional parameters $\left(\mathrm{z}, \varphi_{\mathrm{K}}, \sigma_{\mathrm{K}}\right)$. Increases in the macroeconomic parameters all have predicted Keynesian impacts on capacity utilization and growth in all regimes and have no impact on inequality. Increases in the distributional parameters all increase inequality in all regimes. Increasing capitalist-managers’ ownership share (decreasing workers’ ownership share) and increasing capitalist-managers’ wage bill share (decreasing workers’ wage bill share) increases inequality and lowers growth in all regimes so there is no equality - growth trade-off for these two distributional variables. 
Table 2. Comparative static responses in a wage-led economy.

\begin{tabular}{|l|c|c|c|c|c|c|}
\hline Wage-led & $d \alpha_{0}$ & $d \beta_{\mathrm{K}}$ & $d \beta_{\mathrm{L}}$ & $d \mathrm{z}$ & $d \varphi_{\mathrm{K}}$ & $d \sigma_{\mathrm{K}}$ \\
\hline$d \mathrm{u}$ & + & - & - & - & - & - \\
\hline$d \mathrm{~g}$ & + & - & - & - & - & - \\
\hline$d \psi$ & 0 & 0 & 0 & + & + & + \\
\hline$d \mathrm{u} / d \psi$ & 0 & 0 & 0 & - & - & - \\
\hline$d \mathrm{~g} / d \psi$ & 0 & 0 & 0 & - & - & - \\
\hline
\end{tabular}

Table 3. Comparative static responses in a conflictive economy.

\begin{tabular}{|l|c|c|c|c|c|c|}
\hline Conflictive & $d \omega_{0}$ & $d \beta_{\mathrm{K}}$ & $d \beta_{1}$ & $d z$ & $d \phi_{\mathrm{K}}$ & $d \sigma_{\mathrm{K}}$ \\
\hline$d \mathrm{v}$ & + & - & - & - & - & - \\
\hline$d \mathrm{~g}$ & + & - & - & + & - & - \\
\hline$d \psi$ & 0 & 0 & 0 & + & + & + \\
\hline$d w / d \psi$ & 0 & 0 & 0 & - & - & - \\
\hline$d \mathrm{~g} / d \psi$ & 0 & 0 & 0 & + & - & - \\
\hline
\end{tabular}


Table 4. Comparative static responses in a profit-led economy.

\begin{tabular}{|l|c|c|c|c|c|c|}
\hline Profit-led & $d \alpha_{0}$ & $d \beta_{\mathrm{K}}$ & $d \beta_{\mathrm{L}}$ & $d \mathrm{z}$ & $d \varphi_{\mathrm{K}}$ & $d \sigma_{\mathrm{K}}$ \\
\hline$d \mathrm{u}$ & + & - & - & + & - & - \\
\hline$d \mathrm{~g}$ & + & - & - & + & - & - \\
\hline$d \psi$ & 0 & 0 & 0 & + & + & + \\
\hline$d \mathrm{u} / d \psi$ & 0 & 0 & 0 & + & - & - \\
\hline$d \mathrm{~g} / d \psi$ & 0 & 0 & 0 & + & - & - \\
\hline
\end{tabular}

A higher profit share increases inequality in all regimes, but its impact on capacity utilization and growth varies. In a wage-led regime it lowers both capacity utilization and growth. In a conflictive regime it lowers capacity utilization and raises growth, and in a profit-led regime it raises both capacity utilization and growth. That means there is an equality - growth trade-off in both conflictive and profit-led regimes, and also an equality - capacity utilization trade-off in profit-led regimes.

Lastly, a critical feature revealed by the above analysis is that inequality per se does not impact either growth or capacity utilization. Mathematically speaking, the inequality index does not appear as an argument in the reduced form expressions for either capacity utilization or growth.

Instead, inequality and growth are both impacted by common underlying structural factors determining the pattern of income payments (i.e. the mark-up and profit share, wage shares, and ownership shares) which cause co-movements that create the appearance of a functional relationship. The growth - inequality relationship is a locus and not a 
function.

Furthermore, the sign of the slope of the locus can change as it depends on the underlying impact factors causing the co-movement of inequality and growth. It also depends on the regime character. That means to talk of inequality negatively impacting growth is analytically inaccurate. Any impact stems from mal-distribution of the underlying components of national income which also increases inequality.

\section{Adding wage- and profit-squeeze effects to the neo-Kaleckian model}

So far it has been assumed that the profit share and mark-up are exogenous. This section endogenizes them and links the issue of inequality to the concepts of wage- and profit-squeeze. This helps further understand why the empirical relationship between inequality and growth is so difficult to analyze, and why it is difficult to make simple unambiguous statements about that relationship.

There is an earlier 1970s Marxist literature (see for example Weiskopf, 1979) that framed the income distribution conflict in terms of profit-squeeze. This can be joined with the notion of wage-squeeze and both can incorporated into the neo-Kaleckian growth model by making the profit share a concave function of the rate of capacity utilization (Palley, 2014b), as follows:

(21) $\mathrm{z}=\mathrm{Z}(\mathrm{m}(\mathrm{u}, \lambda)) \quad \mathrm{Z}_{\mathrm{m}}>0, \mathrm{~m}_{\mathrm{u}}>0$ if $\mathrm{u}<\mathrm{u}^{*}, \mathrm{~m}_{\mathrm{u}}=0$ if $\mathrm{u}=\mathrm{u}^{*}, \mathrm{~m}_{\mathrm{u}}<0$ if $\mathrm{u}>\mathrm{u}^{*}, \mathrm{~m}_{\lambda}<0$ $\lambda=$ exogenous factor positively affecting firms’ product market monopoly power or labor market bargaining power. This formulation is illustrated in Figure 7. 
Figure 7. The effect of stronger demand growth on growth and inequality in a wage-led economy with a concave profit share function.

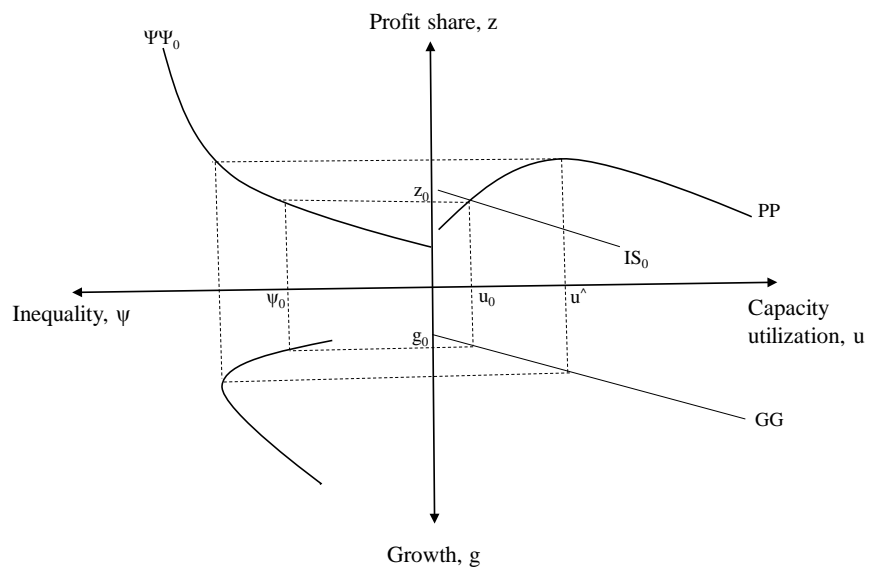

At low rates of capacity utilization the profit share is a positive function of capacity utilization, which generates a wage-squeeze zone. At high levels of capacity utilization the profit share is a negative function of capacity utilization, which generates a profit-squeeze zone. In between, there is a zone when the profit share holds roughly constant and is unaffected by capacity utilization. The economic logic is that at low capacity utilization increased demand gives firms additional market power to raise the mark-up, which squeezes the wage share. However, as capacity utilization increases, labor markets tighten and workers are able to claim a larger share of output and the mark-up falls.

A concave non-linear profit function has important implications for the relationship between growth and inequality. At low rates of capacity utilization, stronger demand conditions $\left(d \alpha_{0}>0, d \beta_{\mathrm{K}}<0, d \beta_{\mathrm{L}}<0\right)$ shift the IS right, which raises capacity utilization and growth. It also raises the profit share and inequality so that the relationship between growth and inequality is positive. At middling rates of capacity utilization, growth and capacity utilization increase but the mark-up and inequality are unchanged. Lastly, at high rates of 
capacity utilization, growth and capacity utilization increase but the mark-up and inequality both fall. Consequently, the relationship between growth and inequality turns negative. These comparative static effects are shown in Table 5 and they hold for all regimes.

Table 5. Comparative static responses to an increase in firms' animal spirits and households' propensity to save in an economy with wage- and profit-squeeze effects.

\begin{tabular}{|l|c|c|c|c|c|c|}
\cline { 2 - 8 } \multicolumn{1}{c|}{} & \multicolumn{3}{c|}{$\mathrm{u}<\mathrm{u}^{*}$} & \multicolumn{4}{c|}{$\mathrm{u}>\mathrm{u}^{*}$} \\
\hline & $d \alpha_{0}$ & $d \beta_{\mathrm{K}}$ & $d \beta_{\mathrm{L}}$ & $d \alpha_{0}$ & $d \beta_{\mathrm{K}}$ & $d \beta_{\mathrm{L}}$ \\
\hline$d \mathrm{u}$ & + & - & - & + & - & - \\
\hline$d \mathrm{~g}$ & + & - & - & + & - & - \\
\hline$d \psi$ & + & - & - & - & + & + \\
\hline$d \mathrm{u} / d \psi$ & + & + & + & - & - & - \\
\hline$d \mathrm{~g} / d \psi$ & + & + & + & - & - & - \\
\hline
\end{tabular}

Graphically, as shown in the southwest quadrant of Figure 7, effect of a including wage- and profit-squeeze effects via a concave profit share function is to make the growth - inequality locus backward-bending in all regimes. The important implication is that, in the presence of a concave profit function, the growth - inequality relationship will depend on the rate of capacity utilization. Inequality will appear good for growth at low rates of capacity utilization, and bad for growth at high rates of capacity utilization.

An increase in firms' power $(\mathrm{d} \lambda>0)$ shifts the profit share function (PP) up; shifts the inequality index function ( $\Psi \Psi$ ) left; shifts the accumulation function (GG) down: and shifts the growth - inequality locus left. This experiment is analogous to the earlier experiment of increasing $\mathrm{z}$. The sign of the comparative statics and the sign of the 
inequality-growth locus depend on whether the economy is wage-led, conflictive or profit-led, and are the same as shown in Tables 2, 3 and 4.

The concave profit share function also complicates the impact of an increase in capitalist-managers' wage share or ownership share, rendering the impact on inequality potentially ambiguous. An increase in either $\left(\mathrm{d} \varphi_{\mathrm{K}}>0, \mathrm{~d} \sigma_{\mathrm{K}}>0\right)$ shifts the IS left, unambiguously lowering capacity utilization and growth. However, the overall impact on inequality is ambiguous. The direct effect is to increase inequality. At high rates of capacity utilization $\left(\mathrm{u}>\mathrm{u}^{\wedge}\right)$, the fall in capacity utilization increases the profit share, which further increases inequality so that inequality rises unambiguously. At low rates of capacity utilization $\left(\mathrm{u}<\mathrm{u}^{\wedge}\right)$, the fall in capacity utilization lowers the profit share so that the overall effect on inequality is ambiguous. These signings are shown in Table 6 and they hold for all regimes.

Table 6. Comparative static responses in an economy with wage- and profit-squeeze effects to a change in wage bill and ownership shares.

\begin{tabular}{|l|c|c|c|c|}
\cline { 2 - 5 } \multicolumn{1}{c|}{} & \multicolumn{2}{c|}{$\mathrm{u}<\mathrm{u}^{\wedge}$} & \multicolumn{2}{c|}{$\mathrm{u}>\mathrm{u}^{\wedge}$} \\
\hline & $d \varphi_{\mathrm{K}}$ & $d \sigma_{\mathrm{K}}$ & $d \varphi_{\mathrm{K}}$ & $d \sigma_{\mathrm{K}}$ \\
\hline$d \mathrm{u}$ & - & - & - & - \\
\hline$d \mathrm{~g}$ & - & - & - & - \\
\hline$d \psi$ & $?$ & $?$ & + & + \\
\hline$d \mathrm{u} / d \psi$ & $?$ & $?$ & - & - \\
\hline$d \mathrm{~g} / d \psi$ & $?$ & $?$ & - & - \\
\hline
\end{tabular}

The theoretical message is that the relationship between growth and inequality is not monotonic; can be positive or negative; and will depend on the structure of the 
economy and the underlying cause of change in inequality. Theory cannot provide a simple unqualified statement about the relationship between growth and inequality. However, it can provide a more limited statement that a higher capitalist-manager ownership share or wage bill share will always lower capacity utilization and growth.

\section{Inequality and growth in the Cambridge model: the short run}

Neo-Kaleckian growth theory assumes capacity utilization is endogenous. In contrast, Cambridge growth theory (Pasinetti, 1962) assumes capacity utilization reverts to a normal rate $\left(\mathrm{u}^{*}\right)$ that is determined by structural factors such as the nature of production technology and the volatility of demand. The Cambridge model is nested in the simple neo-Kaleckian model. All that is involved is reversing the neo-Kaleckian assumptions that capacity utilization is endogenous and the profit share is exogenous. However, doing this significantly changes growth - inequality outcomes, which shows the importance of theory and helps explain divisions among Post Keynesians.

The equations of the model (equations (12) - (18)) are unchanged, but $\mathrm{z}$ is endogenous while $u$ is exogenous and equal to the normal rate of capacity utilization. The model is illustrated in Figure 8. The northeast panel shows the saving and investment functions, with saving being more sensitive to the profit share to ensure stability (i.e. a small increase in the profit share generates a larger increase in saving). The logic of the model rests on Kaldor's (1955/56) Keynesian theory of income distribution, whereby the profit share adjusts to balance saving and investment at normal capacity utilization. The southeast panel determines the rate of growth given the rate of capital accumulation, and the northwest panel determines the inequality index given the profit share. ${ }^{4}$

\footnotetext{
${ }^{4}$ The model can also be represented with an IS schedule drawn in [u, z] space and a capacity utilization condition that imposes $\mathrm{u}=\mathrm{u}^{*}$. If the Keynesian stability condition holds $\left[S_{\mathrm{u}}>I_{\mathrm{u}}\right.$ ], the IS schedule is negatively
} 
Figure 8. The Cambridge model with an index of inequality.

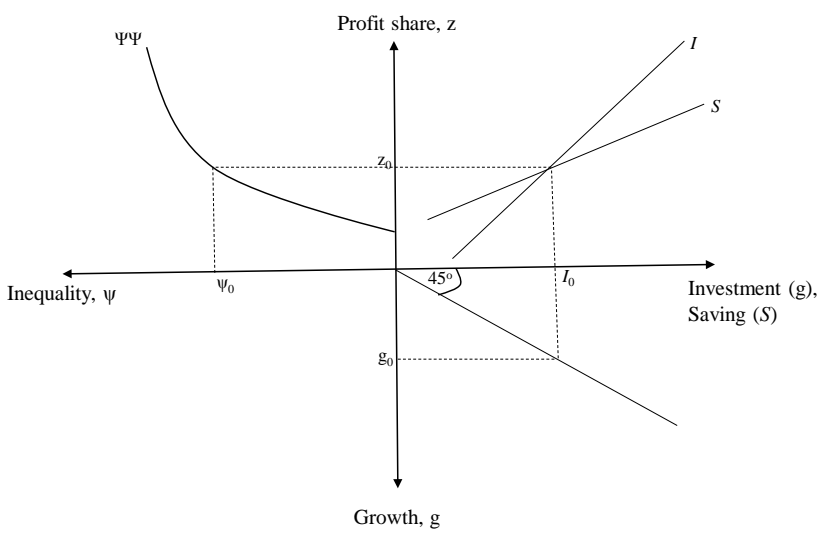

The exogenous variables are $\alpha_{0}, \beta_{\mathrm{K}}, \beta_{\mathrm{L}}, \varphi_{\mathrm{K}}, \sigma_{\mathrm{K}}$, and $\mathrm{u}$. The effect of an increase in firms' animal spirits $\left(\mathrm{d} \alpha_{0}>0\right)$ is shown in Figure 9. The investment function shifts right, raising the equilibrium rate of accumulation and growth. In the goods market, increased investment raises demand for output, raising the mark-up and profit share, which increases inequality ${ }^{5}$. The growth inequality locus is therefore positively sloped.

sloped. However, the IS diagram does not lend itself to four quadrant analysis with a growth - inequality locus, so the paper works with a diagram using the underlying investment and saving functions.

${ }^{5}$ The mechanism can be thought of in terms of Marshallian price adjustment. If nominal wages are fixed, the price level jumps, thereby increasing the mark-up. Alternatively, if nominal wages are rising at a steady rate, the price level jumps and again increases the mark-up. Thereafter, the price level rises at the rate of nominal wage inflation. 
Figure 9. The impact on growth and inequality of an increase in animal spirits in the Cambridge model.

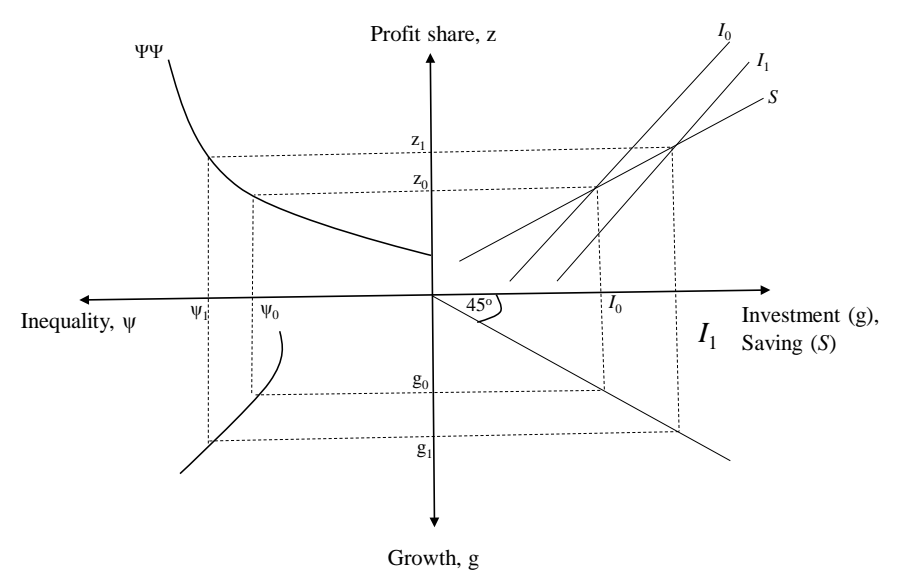

An increase in the propensity to save $\left(d \beta_{K}>0, d \beta_{L}>0\right)$ shifts the saving function right, lowers the profit share, lowers inequality, and lowers accumulation and growth. The profit share falls because reduced output demand lowers the mark-up.

An increase in capitalist-managers' share of the wage bill $\left(\mathrm{d} \varphi_{\mathrm{K}}>0\right)$ increases saving and shifts the saving function right, as shown in Figure 10. That lowers the profit share and reduces the rate of accumulation and growth. The effect on inequality is ambiguous. On one hand, the higher capitalist-manager wage share increases inequality and shifts the inequality index function left. On the other hand, the resulting lower profit share reduces inequality. Figure 10 is drawn for the special case where the two effects cancel out and there is no impact on inequality. Given this ambiguity, the sign of the slope of inequality - growth locus is also ambiguous. The same results and economic logic hold for an increase in capitalist-managers ownership share $\left(\mathrm{d} \sigma_{\mathrm{K}}>0\right)$. 
Figure 10. The effect of an increase in capitalist-managers' wage bill share in the Cambridge model.

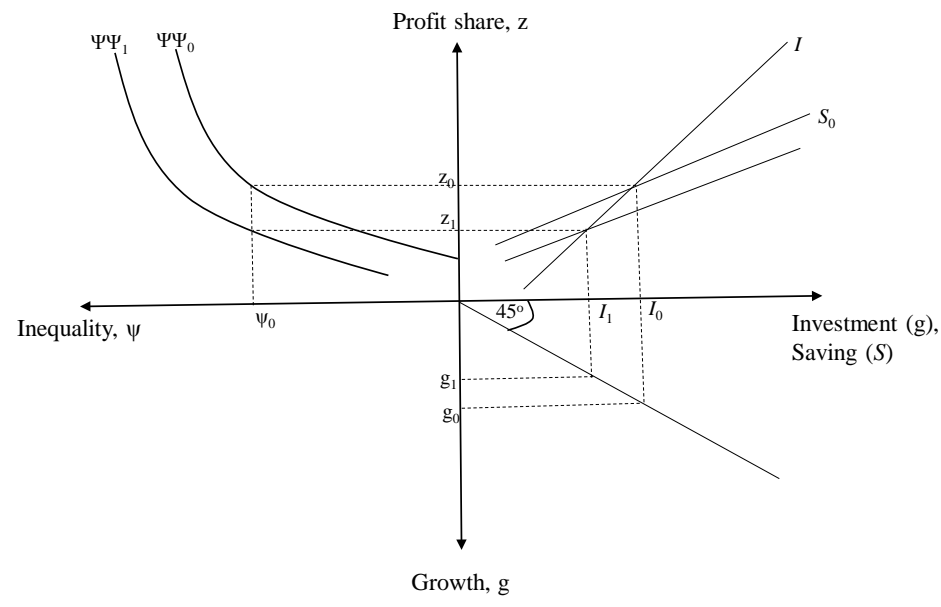

Lastly, an increase in the rate of normal capacity utilization (du $>0$ ) is akin to an increase in the economy's supply capacity. If saving is more sensitive to income than investment, in accordance with the Keynesian expenditure multiplier stability condition, the saving function shifts right by more than the investment function. The profit rate and profit share fall, which lowers the accumulation rate and growth, while inequality falls because of the lower profit share.

In sum, as in the neo-Kaleckian model, inequality per se does not impact growth. Rather, both inequality and growth are impacted by common factors. Furthermore, as shown by inspection of Table 7, inequality and growth tend to be positively correlated, which implies Cambridge growth theory imposes a growth - equality trade-off. The reason is growth depends on the profit share, which is positively impacted by demand. That means taking measures to stimulate demand increases growth, but it also increases inequality via a higher profit share. Improving the distributional parameters increases demand and growth, but also unleashes an increase in the profit share that offsets (and may even reverse) the 
initial distributional improvement.

Table 7. Comparative static responses in the Cambridge model.

\begin{tabular}{|l|c|c|c|c|c|c|}
\hline & $d \alpha_{0}$ & $d \beta_{\mathrm{K}}$ & $d \beta_{\mathrm{L}}$ & $d \varphi_{\mathrm{K}}$ & $d \sigma_{\mathrm{K}}$ & $d \mathrm{u}$ \\
\hline$d \mathrm{~g}$ & + & - & - & - & - & - \\
\hline$d \psi$ & + & - & - & $?$ & $?$ & - \\
\hline$d \mathrm{~g} / d \psi$ & + & + & + & $?$ & $?$ & + \\
\hline
\end{tabular}

\section{Inequality and growth in the neo-Kaleckian model: the long run}

Thus far, the analysis has been of a medium run character in that ownership shares have been held constant. However, ownership shares will change over time if households have differential saving rates.

Building on earlier work by Dutt (1990), Palley (2012) analyzes the role of wealth and wealth distribution in the neo-Kaleckian model. In long-run equilibrium each group must be saving enough to finance a share of capital accumulation equal to its ownership share, thereby maintaining its ownership share. ${ }^{6}$

For a two class economy the long run equilibrium conditions are given by $+++++++$

(22) $I\left(\mathrm{u}, \alpha_{0}, \mathrm{z}\right)=S\left(\mathrm{u}, \sigma_{\mathrm{K}}, \varphi_{\mathrm{K}}, \beta_{\mathrm{K}}, \beta_{\mathrm{L}}\right)$

$$
++++++
$$

(23) $\sigma_{\mathrm{K}} I\left(\mathrm{u}, \alpha_{0}, \mathrm{z}\right)=S_{\mathrm{K}}\left(\mathrm{u}, \sigma_{\mathrm{K}}, \varphi_{\mathrm{K}}, \beta_{\mathrm{K}}\right)$

(24) $\mathrm{g}=I\left(\mathrm{u}, \alpha_{0}, \mathrm{z}\right)$

$$
+++
$$

${ }^{6}$ This is where Pasinetti’s (1962) work becomes important. For a very long time Pasinetti’s Cambridge equation was widely misinterpreted as an IS goods market clearing equation, but it is not. It is an ownership equilibrium condition that has capitalists saving enough to maintain their ownership share. 
(25) $\psi=\Psi\left(\mathrm{z}, \varphi_{\mathrm{K}}, \sigma_{\mathrm{K}}\right)$

Signs above functional arguments represent the signs of the partial derivatives. The long run endogenous variables are capacity utilization (u), capitalist-managers’ ownership share $\left(\sigma_{K}\right)$. The growth rate $(\mathrm{g})$, and inequality $(\psi)$.

Equation (22) is the equation of the IS schedule that ensures goods market equilibrium. Equation (23) is the Cambridge equation for an economy is which capitalist-managers also receive labor income (i.e. managerial pay). The Cambridge equation is often misunderstood to be the goods market equilibrium condition. However, as discussed by Palley (2012), it is an ownership share equilibrium condition that has the capitalist-manager class save the amount needed to finance its ownership share of investment. ${ }^{7}$ Equation (24) is the growth function, and equation (25) is the reduced form of the inequality index given by equation (11.b).

Totally differentiating equations (22) and (23) and arranging in matrix form yields

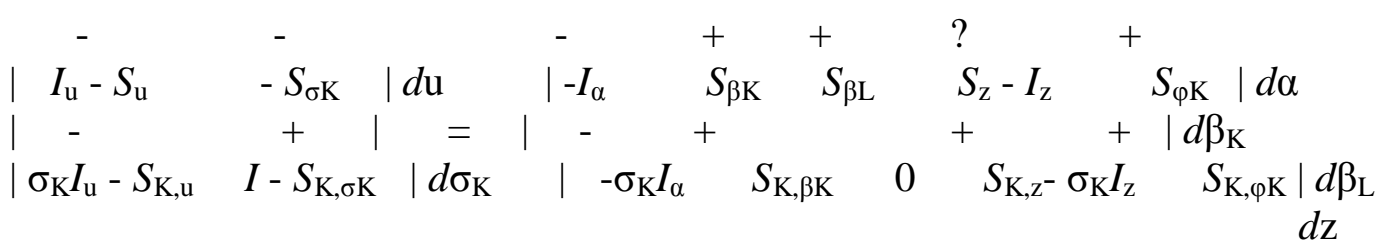

$$
\begin{aligned}
& d \varphi_{\mathrm{K}}
\end{aligned}
$$

The Jacobian matrix, $|\mathrm{J}|$, is negative if saving is more responsive than investment to capacity utilization $\left(\sigma_{\mathrm{K}} I_{\mathrm{u}}-S_{\mathrm{K}, \mathrm{u}}<0, I_{\mathrm{u}}-S_{\mathrm{u}}<0\right)$ and an increase in capitalists' ownership share increases their financing obligation by more than their saving $\left(I-S_{\mathrm{K}, \sigma \mathrm{K}}>0\right)$.

The full model is illustrated in Figure 11. The northwest quadrant shows the

\footnotetext{
${ }^{7}$ The reason the Cambridge equation is often misinterpreted as an IS goods market equilibrium condition is that it is observationally equivalent with the IS in an economy where workers have a propensity to consume of unity and only capitalists save. That behavioral configuration has often been used in neo-Kaleckian models to simply the macroeconomic environment in order to focus on the aggregate demand impact of changes in the profit share.
} 
inequality index function, while the southeast quadrant shows the growth function. The northeast quadrant shows the IS schedule and the ownership equilibrium schedule, denoted KK. The intersection of the two schedules determines the long run equilibrium rate of capacity utilization and capitalist-managers' equilibrium ownership share (which is restricted to lie between 0 and 1 ). If workers save nothing, then capitalist-managers own the entire capital stock.

Figure 11. Long run equilibrium in the neo-Kaleckian model.

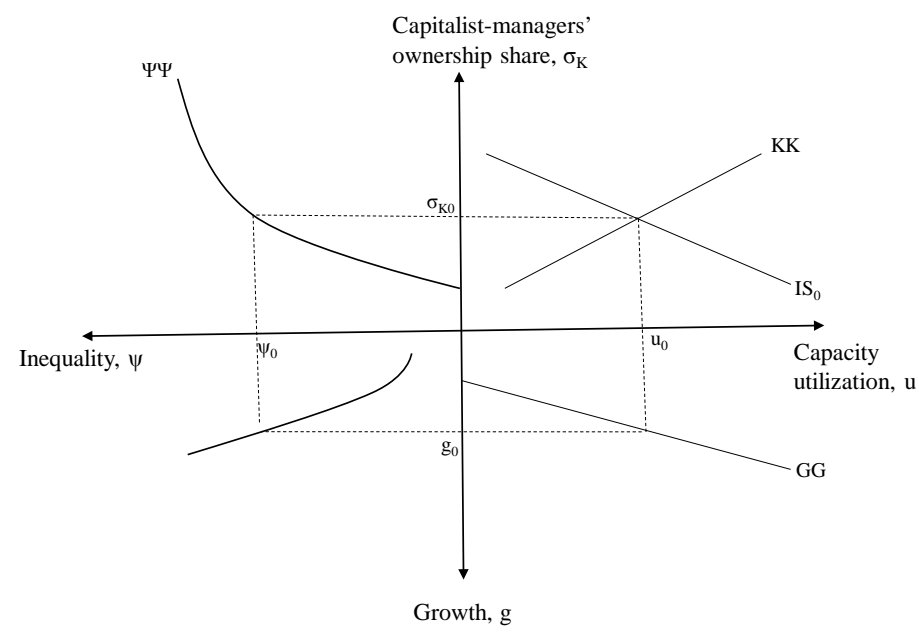

The IS schedule is negatively sloped. ${ }^{8}$ The logic is that increases in capitalist-managers' ownership share increase aggregate saving, which reduces aggregate demand and necessitates a fall in capacity utilization to rebalance saving and investment. The KK schedule is positively sloped. The logic is that a higher capitalist-manager ownership share necessitates a higher level of capacity utilization to generate the income from which capitalist-managers can save to maintain their ownership share. The economy

\footnotetext{
${ }^{8}$ The formal expressions for the slopes of the IS and KK schedules are given respectively by $d \sigma_{K} /\left.d \mathrm{u}\right|_{\mathrm{IS}}=$ $S_{\sigma \mathrm{K}} /\left[I_{\mathrm{u}}-S \mathrm{u}\right]<0$ and $d \sigma_{\mathrm{K}} /\left.d \mathrm{u}\right|_{\mathrm{KK}}=\left[S_{\mathrm{Ku}^{-}}-\sigma_{\mathrm{K}} I_{\mathrm{u}}\right] /\left[I-S_{K, \sigma K}\right]>0$.
} 
converges to the equilibrium by sliding along the IS schedule, gradually bringing saving rates to a position consistent with constant ownership shares.

Table 8 shows the comparative statics. An increase in animal spirits $\left(d \alpha_{0}>0\right)$ shifts the IS right. It also shifts the KK schedule (ownership equilibrium) right. The logic is capitalist-managers need additional income to finance increased investment and maintain their ownership share. Capacity utilization and growth unambiguously increase. However, the impact on ownership shares is ambiguous. If capitalist-managers have a high propensity to save ( $S_{\mathrm{K}, \varphi \mathrm{K}}$ large), the KK schedule shifts less because they need less additional income and their ownership share rises, as does inequality.

Table 8. Long run comparative static responses for the neo-Kaleckian model.

\begin{tabular}{|l|c|c|c|c|c|}
\hline & $d \alpha_{0}$ & $d \beta_{\mathrm{K}}$ & $d \beta_{\mathrm{L}}$ & $d \mathrm{z}$ & $d \varphi_{\mathrm{K}}$ \\
\hline$d \mathrm{u}$ & + & - & - & $?$ & - \\
\hline$d \sigma_{\mathrm{K}}$ & $?$ & $+/ ?$ & - & $?$ & + \\
\hline$d \mathrm{~g}$ & + & - & - & $?$ & - \\
\hline$d \psi$ & $?$ & $+/ ?$ & - & $+/ ?$ & + \\
\hline$d \mathrm{u} / d \psi$ & $?$ & $-/ ?$ & + & $?$ & - \\
\hline$d \mathrm{~g} / d \psi$ & $?$ & $-/ ?$ & + & $?$ & - \\
\hline
\end{tabular}

An increase in capitalist-managers propensity to save $\left(d \beta_{K}>0\right)$ shifts both the IS and KK schedules left so that capacity utilization and growth fall. Their ownership share and inequality increase if $\left|I_{\mathrm{u}}-S_{\mathrm{u}}\right|>\left|\sigma_{\mathrm{K}} I_{\mathrm{u}}-S_{\mathrm{K}, \mathrm{u}}\right|$. Capitalist-managers can increase their ownership share by saving more, and this increases inequality.

An increase in workers' propensity to save $\left(d \beta_{\mathrm{L}}>0\right)$ shifts the IS left, while the KK schedule is unaffected. Capacity utilization and growth fall, capitalist-managers’ 
ownership share falls, and inequality falls. Workers can save their way to a greater ownership position but it comes at the cost of depressed conditions. This outcome is illustrated in Figure 12.

Figure 12. Long run response to an increase in workers' propensity to save $\left(d \beta_{\mathrm{L}}>0\right)$ in the neo-Kaleckian model.

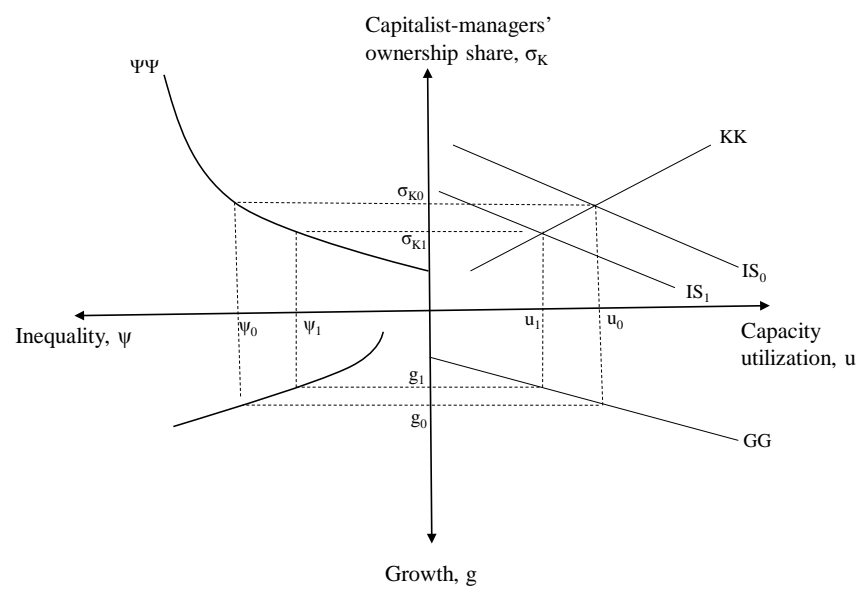

The effect of an increase in the profit share $(d z>0)$ is ambiguous regarding all variables. The wage-led $\left(S_{z}-I_{z}>0\right)$, conflictive $\left(S_{z}-I_{z}>0\right)$, profit-led $\left(S_{z}-I_{z}<0\right)$ distinction is important here. If the economy is wage-led or conflictive, the IS schedule will shift left as capacity utilization contracts. If it is profit-led, the IS schedule will shift right as capacity utilization increases. The direction of shift of the KK schedule is also impacted by the regime character. If the economy is wage-led, the KK shifts left as capitalist-managers' saving increases due to a higher profit share but investment is little changed. Consequently, lower income is needed for capitalist-managers to save only an amount sufficient to maintain their existing ownership share. If the economy is conflictive or profit-led the KK schedule may shift right. As regards inequality, the inequality function in the northwest quadrant shifts left. If ownership shares are unchanged or if capitalist managers' ownership 
share increases, inequality will unambiguously increase.

The final experiment is an increase in capitalist-managers' share of the wage bill $\left(d \varphi_{K}>0\right)$ which is shown in Figure 13. The increase their wage share shifts the inequality index function left. It also shifts the IS and KK schedules left so that capacity utilization and growth fall, and capitalist-managers' ownership share and inequality increase. ${ }^{9}$ In effect, an increase in capitalist-managers' share of the wage bill is a recipe for stagnation with increased inequality, which is exactly what many countries are now experiencing.

Figure 13. Long run response to an increase in capitalist-managers share of the wage bill $\left(d \varphi_{K}>0\right)$ in the neo-Kaleckian model.

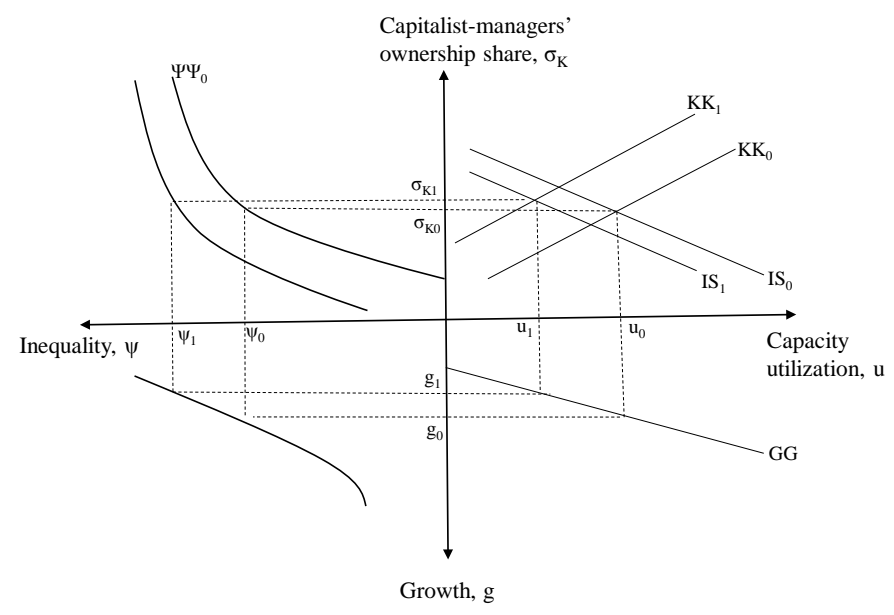

In sum, the long run neo-Kaleckian model allows for endogenous ownership shares. Changes in distributional parameters have both a direct and indirect effect. The direct effect is the immediate impact on income distribution and demand. The indirect effect is the induced impact on income distribution and demand that comes from changes in ownership shares caused by changed relative saving rates.

\footnotetext{
${ }^{9}$ The impact on ownership is given by $d \sigma_{\mathrm{K}} / d \varphi_{\mathrm{K}}=\left\{\left[I_{\mathrm{u}}-S_{\mathrm{u}}\right]\left[S_{\mathrm{K}, \varphi \mathrm{K}}\right]-\left[\sigma_{\mathrm{K}} I_{\mathrm{u}}-S_{\mathrm{K}, \mathrm{u}}\right]\left[S_{\varphi \mathrm{K}}\right]\right\} / \mathrm{J} \mid>0$ as $S_{\mathrm{K}, \varphi \mathrm{K}}>S_{\varphi \mathrm{K}}$ and $\left|I_{\mathrm{u}}-S_{\mathrm{u}}\right|$ $>\left|\sigma_{\mathrm{K}} I_{\mathrm{u}}-S_{\mathrm{K}, \mathrm{u}}\right| \cdot$
} 
In the long run model it is still the case that inequality per se has no impact on capacity utilization and growth. Instead, inequality, capacity utilization and growth are all impacted by common underlying factors regarding the pattern of income division. That generates co-movements in the variables that give the appearance of a functional relationship when there is none. Lastly, the relationship that is traced out by these co-movements can be positive or negative, depending on the underlying factor. Higher inequality can be associated with lower capacity utilization and slower growth, and it can also be associated with higher capacity utilization and faster growth. The nature of the relationship depends on the economic regime character and the underlying factor causing the change.

\section{Inequality and growth in the Cambridge model: the long-run}

In the basic neo-Kaleckian model the long-run endogenous variables are capacity utilization (u) and ownership shares $\left(\sigma_{\mathrm{K}}+\sigma_{\mathrm{L}}=1\right)$. In the Cambridge model capacity utilization is exogenously given as equal to the normal rate $\left(\mathrm{u}=\mathrm{u}^{*}\right)$ and the long-run endogenous variables are the profit share (z) and ownership shares $\left(\sigma_{\mathrm{K}}+\sigma_{\mathrm{L}}=1\right)$.

The underlying economic logic of the long-run model is simple. Functional income distribution shares are determined in the goods market according to Kaldor's (1955/56) Keynesian theory of income distribution, with the profit share adjusting to ensure aggregate demand equals normal rate of capacity utilization output. Relative saving rates of the two classes of household determines the evolution of household ownership shares. The economy is in long-run equilibrium when the goods market clears and Pasinetti's (1962) Cambridge equation holds so that each class' saving out of income is just sufficient to maintain its ownership share. 
For a two household class economy the long run equilibrium conditions are given

by

$+++++++$

(26) $I\left(\mathrm{z}, \alpha_{0}, \mathrm{u}^{*}\right)=S\left(\mathrm{z}, \sigma_{\mathrm{K}}, \varphi_{\mathrm{K}}, \beta_{\mathrm{K}}, \beta_{\mathrm{L}}, \mathrm{u}^{*}\right)$

$++++++++$

(27) $\sigma_{\mathrm{K}} I\left(\mathrm{z}, \alpha_{0}, \mathrm{u}^{*}\right)=S_{\mathrm{K}}\left(\mathrm{z}, \sigma_{\mathrm{K}}, \varphi_{\mathrm{K}}, \beta_{\mathrm{K}}, \mathrm{u}^{*}\right)$

(28) $\mathrm{g}=I\left(\mathrm{z}, \alpha_{0}, \mathrm{u}^{*}\right)$

$+++$

(29) $\psi=\Psi\left(\mathrm{z}, \varphi_{\mathrm{K}}, \sigma_{\mathrm{K}}\right)$

Signs above functional arguments represent signs of partial derivatives. The long run endogenous variables are the profit share $(\mathrm{z})$, capitalist-managers' ownership share $\left(\sigma_{\mathrm{K}}\right)$, the growth rate (g) and inequality $(\psi)$.

Equation (26) is the IS equation ensuring goods market clearing. Equation (27) is the Cambridge equation ensuring ownership equilibrium and has capitalist-managers saving the amount needed to finance their share of investment. Equation (28) is the accumulation and growth function, while equation (30) is the inequality index.

The slopes of the IS and KK schedules are given respectively by

$d \mathrm{z} /\left.d \sigma_{\mathrm{K}}\right|_{\mathrm{IS}}=S_{\sigma \mathrm{K}} /\left[I_{\mathrm{z}}-S_{\mathrm{z}}\right]<0$

$d \mathrm{z} /\left.d \sigma_{\mathrm{K}}\right|_{\mathrm{KK}}=\left[S_{K, \sigma \mathrm{K}}-\Pi\right] /\left[\sigma_{\mathrm{K}} I_{\mathrm{z}}-S_{\mathrm{K}, \mathrm{z}}\right]<0$

The model is illustrated in Figure 14. The IS schedule is negatively sloped because an increase in the profit share increases saving and that requires a lower capitalist ownership share to reduce saving and maintain goods market equilibrium. The KK is negatively sloped because an increase in the ownership share means capitalist-managers receive more 
profit income (which is based on the total capital stock) and the profit share must fall so they do not save more than is needed to finance their share of investment. ${ }^{10}$

Figure 14. Long run equilibrium in the Cambridge model $\left(\psi_{1}>\psi_{0}\right)$.

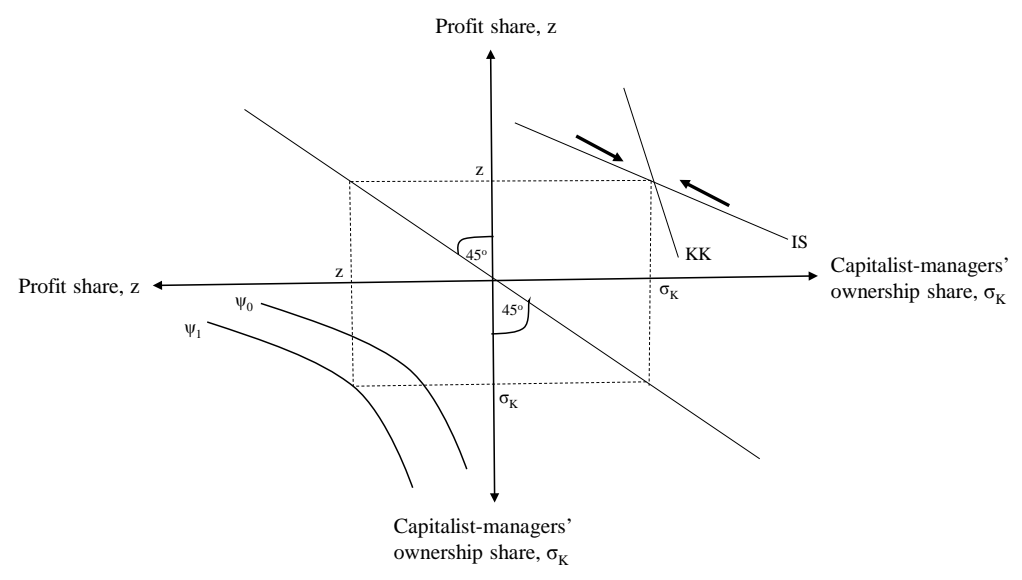

The KK schedule is drawn with a steeper absolute slope than the IS schedule. This is required for stability and can be understood as follows. Consider a point on the IS below the KK. Reading across to the KK, that profit share implies a higher equilibrium capitalist ownership shares, which means capitalists are saving more than needed to maintain their current ownership share. Capitalists’ ownership share starts to increase and the economy slides down the IS until the point of intersection with the KK, at which time general equilibrium is established. If the IS had a steeper absolute slope, the economy would be unstable as the dynamics would move it away from the intersection of the IS and KK schedules.

The southwest quadrant of Figure 14 tracks out iso-iequality contours along which the inequality index is constant. The contours are negatively sloped as an increased profit

\footnotetext{
${ }^{10}$ The slope of the KK schedule is counter-intuitive. As the profit share falls, capitalists' equilibrium ownership share falls. The reason is because the profit rate drives accumulation. A lower profit share lowers the profit rate and accumulation, so that capitalists end up owning a larger share of a diminished capital stock.
} 
share increases inequality, requiring a lower capitalist-manager ownership share to hold inequality constant. Contours closer to the origin are associated with lower levels of inequality.

Totally differentiating equations (26) and (27) and arranging in matrix form yields

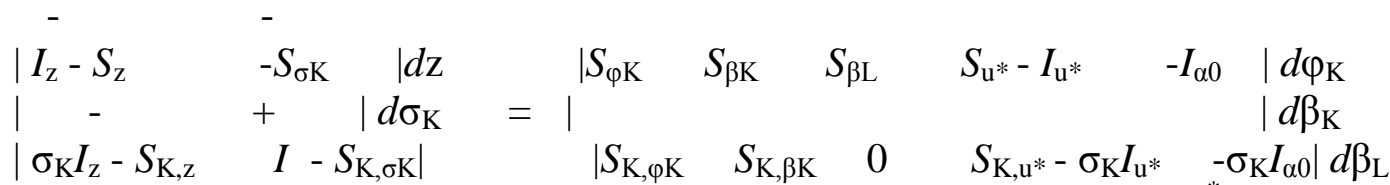

$$
\begin{aligned}
& d \mathrm{u}^{*} \\
& d \alpha_{0}
\end{aligned}
$$

The sign of the Jacobian matrix is $|\mathrm{J}|=\left[I_{\mathrm{z}}-S_{\mathrm{Z}}\right]\left[I-S_{\mathrm{K}, \sigma \mathrm{K}}\right]-\left[\sigma_{\mathrm{K}} I_{\mathrm{Z}}-S_{\mathrm{K}, \mathrm{Z}}\right]\left[-S_{\sigma \mathrm{K}}\right]<0 .{ }^{11}$

We can now consider several different comparative static experiments and their impact on inequality and growth. The signings of these experiments are shown in Table 9. The first experiment is an increase in capitalist-managers' wage share $\left(d \varphi_{\mathrm{K}}>0\right)$. This shifts the IS schedule down and the KK schedule right so that the profit share falls $(d z<0)$ and capitalists' ownership share increases $\left(d \sigma_{K}>0\right)$. The IS shifts down because the increase in capitalist-managers' wage share increases aggregate saving and lowers $\mathrm{AD}$, requiring a lower profit share to clear the goods market. The KK shifts right because capitalists must own a larger share of the capital stock for their required investment to absorb their saving. ${ }^{12}$ Growth falls because the lower profit share lowers the profit rate and rate of accumulation. However, the impact on income inequality is ambiguous. The increase in capitalists' wage share $\left(\varphi_{K}\right)$ and ownership share $\left(\sigma_{K}\right)$ both increase inequality, but the fall in the profit share (z) lowers it. The ambiguity regarding the direction of change of

\footnotetext{
${ }^{11}$ This assumes $I-S_{\mathrm{K}, \sigma \mathrm{K}}>0$ so that an increase in capitalists' ownership share increases their funding requirement by more than it increases their saving. The term $\left[\sigma_{\mathrm{K}} I_{\mathrm{Z}}-S_{\mathrm{K}, \mathrm{z}}\right]$ is negative because stability requires saving to be more sensitive to the profit share than investment.

${ }^{12}$ The formal signing of this effect is $d \sigma_{\mathrm{K}} / d \varphi_{\mathrm{K}}=\left\{\left[I_{\mathrm{Z}}-S_{\mathrm{z}}\right]\left[S_{\mathrm{K}, \varphi \mathrm{K}}\right]-\left[\sigma_{\mathrm{K}} I_{\mathrm{z}}-S_{\mathrm{K}, z}\right]\left[S_{\varphi \mathrm{K}}\right]\right\} /|\mathrm{J}|>0$ because $S_{\mathrm{K}, \varphi \mathrm{K}}>S_{\varphi \mathrm{K}}$ and $I_{\mathrm{z}}-S_{\mathrm{z}}>\sigma_{\mathrm{K}} I_{\mathrm{Z}}-S_{\mathrm{K}, \mathrm{z}}$ because $I_{\mathrm{z}}>\sigma_{\mathrm{K}} I_{\mathrm{z}}$ and $S_{\mathrm{z}}<S_{\mathrm{K}, \mathrm{z}}$.
} 
inequality is a feature of the Cambridge model and reflects a stabilizing aspect of the Cambridge economy. Structural changes that increase income inequality cause AD to fall, which unleashes adjustments that lower the profit share in accordance with Kaldor's (1956) theory of income distribution.

Table 9. Long run comparative static responses for the Cambridge model.

\begin{tabular}{|l|c|c|c|c|c|}
\hline & $d \alpha_{0}$ & $d \beta_{\mathrm{K}}$ & $d \beta_{\mathrm{L}}$ & $d \mathrm{u}^{*}$ & $d \varphi_{\mathrm{K}}$ \\
\hline$d z$ & - & - & - & - & + \\
\hline$d \sigma_{\mathrm{K}}$ & + & + & + & - & + \\
\hline$d \mathrm{~g}$ & - & - & - & $? /+$ & + \\
\hline$d \psi$ & $?$ & $?$ & $?$ & - & + \\
\hline$d \mathrm{u} / d \psi$ & $?$ & $?$ & $?$ & - & $?$ \\
\hline$d \mathrm{~g} / d \psi$ & $?$ & $?$ & $?$ & - & + \\
\hline
\end{tabular}

The second experiment is an increase in capitalists' propensity to save $\left(d \beta_{K}>0\right)$. This shifts the IS down and shifts the KK right so that the profit share falls $(d z<0)$ and capitalists' ownership share rise $\left(d \sigma_{K}>0\right)$. Higher capitalist saving reduces $A D$, causing the profit share to fall. Higher capitalist saving also requires a larger capitalist ownership share so that their investment funding obligation matches their higher saving. Once again, growth falls while the impact on inequality is ambiguous for the same reasons as before.

The third experiment is an increase in workers' propensity to save $\left(d \beta_{\mathrm{L}}>0\right)$. This shifts the IS down but the KK is unaffected. The profit share falls $(d z<0)$ because increased worker saving lowers AD. Rather surprisingly, capitalists’ ownership share increases $\left(d \sigma_{K}>0\right)$. The reason is a lower profit share lowers the profit rate and causes a 
larger percentage decline in investment so that capitalists actually increase their share of ownership of the capital stock. Again, growth falls and the impact on inequality is ambiguous.

The fourth experiment is an increase in the normal rate of capacity utilization $\left(d \mathrm{u}^{*}\right.$ $>0$ ). Assuming the Keynesian multiplier stability condition holds so that saving is more sensitive to capacity utilization than investment $\left(S_{\mathrm{u}^{*}}-I_{\mathrm{u}^{*}}>0\right)$, the IS shifts down because of increased saving. The KK schedule also shifts down, so that the net result is that both the profit share and capitalists' ownership share fall $\left(d z<0, d \sigma_{K}<0\right)$. Higher capacity utilization raises saving which lowers the profit share. It also increases investment via the impact on the profit rate but capitalists' ownership share falls because of their reduced share of total saving. Income inequality therefore unambiguously falls in response to a higher rate of normal capacity utilization. Assuming the initial positive capacity utilization - profit rate impact dominates the subsequent profit share - profit rate decline, accumulation and growth increase. Inequality and growth are negatively correlated.

The fifth and final experiment is an increase in autonomous investment $\left(d \alpha_{0}>0\right)$. This increases AD and shifts the IS up. It also shifts the KK up as the higher profit share enables capitalists' to fund an increased share of the investment, which increases their ownership share. Growth increases because of the higher profit share and profit rate. Since both the profit share and capitalists' ownership share increase $\left(d z>0, d \sigma_{K}>0\right)$, inequality unambiguously increases. Growth and inequality are therefore positively correlated.

Increases in normal capacity utilization and autonomous investment have differently signed impacts on inequality. Increased autonomous investment raises the profit share because it increases $\mathrm{AD}$, and it also raises the profit rate and growth. Increased 
capacity utilization lowers the profit share because it increases saving and lowers $\mathrm{AD}$, but it also simultaneously raises the profit rate and growth.

\section{Taking stock: comparing the neo-Kaleckian and Cambridge models}

The previous sections have examined two core Post Keynesian models of growth and income distribution, showing the relationship between growth and inequality in both the short and long run. This section takes stock of the analysis and compares the models.

Post Keynesians have historically focused on the functional distribution of income. Inequality is concerned with household income distribution. Linking the two requires adding the distribution of the wage bill and ownership shares.

In both models there is need to distinguish between short and long run growth inequality correlations. Short run analysis holds ownership shares constant so that household profit shares are fixed. Long run analysis allows ownership shares to vary.

In both models inequality is a generated variable. Inequality per se does not therefore impact growth. Instead, growth and inequality are both impacted by underlying changes to the functional distribution of income, the distribution of the wage bill, and economic behaviors such as saving propensities.

Despite both models being Post Keynesian, there are fundamental analytical differences. The Cambridge model is a full employment normal/capacity utilization model. That means there are no Keynesian $\mathrm{AD}$ effects on output, but there are $\mathrm{AD}$ effects on income distribution via Kaldor's (1956) theory of income distribution. Since income distribution affects growth, that means $\mathrm{AD}$ affects growth. In the Cambridge model, the functional distribution of income is determined by the pressure of AD. It is Marshallian in 
spirit and "power" is absent. However, power considerations can be introduced through the backdoor channel of having power impact the distribution of the wage bill (Palley, 2013).

The neo-Kaleckian model is a less than full employment/variable capacity utilization model and there are Keynesian AD effects on output. The functional distribution of income is determined by power which impacts the mark-up. However, AD effects on income distribution can be introduced by having the mark-up depend on capacity utilization. Growth is affected by both power and AD since it depends on both functional income distribution and capacity utilization.

In sum, normal versus variable capacity utilization is one key difference. A second difference is demand pressure versus power as the determinant of income distribution, though this difference can be blurred by amendments to each model.

In both models there is no clear cut relation between growth and income inequality and the sign of the relation depends on the underlying change. For most experiments, the short run Cambridge model tends to suggest the economy is bound by a growth inequality trade-off because the profit share must increase to raise growth. The long run Cambridge model is ambiguous because of induced ownership share effects that may reverse the initial rise in inequality. The short run neo-Kaleckian model suggests increased growth is compatible with lower inequality, except for the profit-led regime.

Both models suggest that increasing worker saving to reduce inequality is a bad idea as it lowers growth. In the Cambridge model, increased worker saving lowers AD, the profit rate and growth. In the neo-Kaleckian model it lowers $\mathrm{AD}$, capacity utilization and growth. 
Both models also suggest redistributing the wage bill from capitalist-managers to workers lowers inequality and increases growth. That is because it increases $\mathrm{AD}$, raising the profit rate and growth in the Cambridge model, and raising capacity utilization and growth in the neo-Kaleckian model. Furthermore, in the neo-Kaleckian model, increasing workers' share of the wage bill also inclines the economy to be wage-led (Palley, 2015a). That suggests policy should focus on reducing wage inequality, but that poses a political problem as such a policy is likely to divides the middle class from the working class (Palley, 2015b).

More generally, the big take-away for policy is that there is no inevitable trade-off between growth and inequality. Instead, both models suggest it is possible to craft a policy mix that both increases growth and lowers inequality.

Lastly, the fact that the sign of the growth - inequality locus varies across theories and within theories (i.e. depends on circumstance and cause of change), means econometric estimates of the relation require careful consideration. Single equation estimates of the growth - inequality relation are likely to be highly unreliable. Instead, it would be better to estimate separate growth and inequality equations that incorporate the deep structural factors influencing the endogenous variables, and then see how growth and inequality co-move in response to changes in those factors. An example of this structural estimation approach is provided by Belabed et al. (2013).

\section{Is there a causal role for inequality?}

The above analysis has emphasized that inequality and growth co-move, but inequality per se has no causal role. However, from another angle inequality is absolutely critical in producing the results of the neo-Kaleckian and Cambridge models. 
The critical assumption in both models is that worker households have a higher propensity to spend and lower propensity to save than capitalist-manager households. That raises the question what is the microeconomic justification for this assumption, and it is here that inequality becomes critical.

Palley (2010) presents a "relative permanent income" theory of consumption that synthesizes the consumption theories of Keynes (1936), Duesenberry (1948), and Friedman (1957). The key feature of the theory is that the share of permanent income devoted to consumption by a household is a negative function of household relative permanent income.

Relative permanent income theory predicts patterns of consumption spending that are consistent with both long-run time series data for aggregate consumption and empirical findings from cross-section data showing high-income households have a higher propensity to save. It also explains why consumption inequality is less than income inequality. Furthermore, it explains why households with lower relative permanent income will tend to have a higher propensity to consume and a lower propensity to save. It therefore provides the micro-foundations for the consumption and saving behavior in the neo-Kaleckian and Cambridge models.

Since worker households have lower relative permanent income, they have a higher propensity to consume and a lower propensity to save. Moreover, since wage income is disproportionately concentrated in such households, the average propensity to consume out of wage income exceeds that out of profit income. However, this is all conditional on the existence of inequality which gives rise to different relative household permanent income. Absent such inequality, all households would have the same propensity to consume and 
save and the pattern of relations observed between inequality, capacity utilization and growth would evaporate. That makes inequality per se absolutely critical to the neo-Kaleckian and Cambridge models, but it is causal in a subterranean manner rather than having a direct impact on growth and capacity utilization.

Lastly, permanent relative income theory makes the distinction between worker and capitalist households unnecessary. Instead, the economy consists of high income and low income households, and it is that income distinction that generates different consumption and saving behavior. Class distinctions can still matter, but they concern explanations of political understanding and interest rather than consumption and saving behavior.

\section{Conclusion: extending the model to a multi-class economy}

Finally, in principle it is possible to extend the neo-Kaleckian and Cambridge models to a multi-class economy. Palley (2015b) presents a three class neo-Kaleckian model with capitalists, managers, and workers. The key feature is that capitalists and managers save and own the capital stock, while workers consume all their income and own nothing. Additionally, capitalists only receive profit income whereas managers receive both profit and wage income. In terms of the US economy, capitalists are identified with the one percent, managers constitute the middle class that has an ownership stake and represent the next nineteen percent, and workers represent the bottom eighty percent.

A three class model of the economy allows for richer measures of inequality. The one percent inequality index would be given by (26) $\psi_{1}=\mathrm{y}_{\mathrm{K}} /\left[\mathrm{y}_{\mathrm{M}}+\mathrm{y}_{\mathrm{W}}\right]$

The twenty-eighty percent inequality index would be given by 
(27) $\psi_{20}=\left[y_{K}+y_{M}\right] / y_{W}$

From a theoretical perspective, a multi-class model adds greatly to analytical complexity and adds little to understanding the process determining growth and distribution. Instead, the major benefit is enriching the political economy of capitalist economies, making clear the ambivalent interests of the middle class which has shared interests and conflicts with both capitalists and workers. On one hand, as a property owning class, the middle class has an interest in a higher profit share, which aligns it with the capitalist class against the working class. On the other hand, as wage income recipients, the middle class has an alignment with the working class to achieve a bigger wage share. However, it is also directly in conflict with the working class over the division of the wage bill between the two classes.

Lastly, Kalecki (1970) argued capitalists also receive wage income (e.g. CEO pay) which should be treated as a deduction from the profit share. In that case, the middle class has a double conflict with the capitalist class over the CEO pay deduction from profits and increased profit share at the expense of wage share. The middle class also has a double conflict with the working class over the division of the wage bill and the negative effect of an increased wage share on the profit share. How, the middle class sides politically likely depends significantly on its perception of these economic conflicts of interest and the relative size of the stakes. 


\section{References}

Belabed, C.A., Theobold, T., and van Treek, T. (2013), "Income distribution and current account imbalances,” IMK Working Paper No. 126, IMK, Dusseldorf, Germany.

Bhaduri, A. and S.A. Marglin (1990), "Unemployment and the real wage: the economic basis for contesting political ideologies," Cambridge Journal of Economics, 14: 375 - 93.

Blecker, R. (2002), "Distribution, demand and growth in neo-Kaleckian macro-models," in M. Setterfield (ed.), The Economics of Demand-led Growth: Challenging the Supply-side Vision of the Long Run, Edward Elgar, Cheltenham: UK.

Carvalho, L. and Rezai, A. (2015), "Personal income inequality and aggregate demand," Cambridge Journal of Economics, published online, March 15.

Duesenberry, J.S. (1949), Income, Saving and the Theory of Consumption Behavior, Cambridge, Mass.: Harvard University Press.

Dutt, A.K. (1984), "Stagnation, income distribution and monopoly power," Cambridge Journal of Economics, 8, 25 - 40.

(1990), "Growth, Distribution and Capital Ownership: Kalecki and Pasinetti Revisited,” in B. Dutta, S. Gangopadhayay, D. Mookherjee, and D. Ray (eds.), Economic Theory and Policy: Essays in Honor of Dipak Banerjee, Bombay: Oxford University Press.

Friedman, M. (1956), A Theory of the Consumption Function, Princeton: Princeton University Press.

Kaldor, N. (1955/56), “Alternative Theories of Distribution,” Review of Economic Studies, 7, $83-100$.

Kalecki, M. (1970): "The class struggle and the distribution of national income,” Kyklos, 24(1), p.1-8.

Keynes, J.M. (1936), The General Theory of Employment, Interest, and Money, London: Macmillan.

Palley, T.I. (2005), "Class conflict and the Cambridge theory of distribution,” in B. Gibson (ed.), The Economics of Joan Robinson: A Centennial Celebration, Cheltenham: E. Elgar.

---------- (2010), “The Relative Permanent Income Theory of Consumption: A Synthetic Keynes-Duesenberry-Friedman Model,” Review of Political Economy, 1 (January), 41 56

(2012), "Wealth and Wealth Distribution in the Neo-Kaleckian Growth Model.” Journal of Post Keynesian Economics, 34 (Spring 2012), 449 - 470. 
---------- (2013), “A Kaldor - Hicks - Goodwin - Tobin - Kalecki model of growth and distribution,” Metroeconomica, 64 (2013), 319 - 345.

(2014a), “The middle class in macroeconomics and growth theory: A three class neo-Kaleckian-Goodwin model,” Cambridge Journal of Economics, 38 (6) (November), $1355-1372$.

(2014b), "Enriching the neo-Kaleckian growth model: Nonlinearities, political economy, and q theory,” in S. Dullien, E. Hein and A. Truger (eds.), Macroeconomics, Development and Economic Policies: Festschrift for Jan Priewe, Metropolis-Verlag: Marburg.

(2015a), "Wage- vs. profit-led growth: the role of the distribution of wages in determining regime character,” Cambridge Journal of Economics, forthcoming.

----------(2015b) “The middle class in macroeconomics and growth theory: A three class neo-Kaleckian-Goodwin model,” Cambridge Journal of Economics, 39(1), 221 - 243.

Pasinetti, L. (1962), "Rate of Profit and Income Distribution in Relation to the Rate of Economic Growth,” Review of Economic Studies, 29, 267 - 79.

Piketty, T. (2014), Capital in the Twenty-First Century, Bellknap Press of Harvard University: Cambridge, MA.

Rowthorn, R. 1982, Demand, real wages and growth, Studi Economici, 19, 3 - 54.

Taylor, L. 1983, Structuralist Macroeconomics, Basic Books: New York.

Weiskopff, T.E. (1979), "Marxian Crisis Theory and the rate of Profit in the post-war US economy”, Cambridge Journal of Economics, 3 (4) December, 341-378. 
Publisher: Hans-Böckler-Stiftung, Hans-Böckler-Str. 39, 40476 Düsseldorf, Germany Phone: +49-211-7778-331, IMK@boeckler.de, http://www.imk-boeckler.de

IMK Working Paper is an online publication series available at: http://www.boeckler.de/imk 5016.htm

ISSN: $1861-2199$

The views expressed in this paper do not necessarily reflect those of the IMK or the Hans-Böckler-Foundation.

All rights reserved. Reproduction for educational and non-commercial purposes is permitted provided that the source is acknowledged. 